\section{A conversation with former editor-in-chief of Parents Magazine and editor of On Four Walls}

\section{Fran Fearnley and Ray Chodzinski}

$\mathrm{I}$ Wrote on All Four Walls: Teens Speak Out on Violence edited by Fran Fearnley is a disturbing yet truthful account of how teens, abused and bullied, somehow survive the brutality of their existence and manage to find meaning in their lives despite everything that happens to them. The book sponsored by the Toronto Public Library system is the first in a series of publications that seeks to give voice to the stories, thoughts and poems of teens living in the city of Toronto. Josephine Bryant, City Librarian, Toronto public Library writes, "here are the powerful stories of youth who agreed to share their experiences and their stories. It is an attempt to bring a positive approach to the issue of street youth." Fran Fearnley says Adam, Allan, Caitlin, Claire, Debbie, Don, Janice, Kevin and Sue told us about their encounters with violence in one on one-taped interviews. Their very own words transcribed from those interviews, are what you will read. They are authentic oral testimonies as told to an empathetic listener. Dr. Fred Mathews a social worker with Central Toronto Youth Services concludes the book with advice to children and teens about what to do if they or others are or know of someone in need. He reminds young people "they must learn to trust teachers and educators and tell a teacher, principal, school worker, or other adult. If they do not listen, tell a police officer, a nurse, parents, a friend but tell someone. Don't let previous negative experiences with some adults in power affect your decision, keep trying until you find someone who will believe you and take action. The important thing is do not stand by and let others be harmed. Violence is fueled by silence and stops when we all take a

I met Ms. Fearnley while we were taping a segment for the syndicated television show FINEPRINT hosted by Carolyn Weaver. The show features shared views about violence and bullying behaviours experienced by children and teens. Fran's book, I Wrote on All Four Walls and my book, Bullying a Crisis in our Schools and our Communities were featured.

Since this issue focuses on child and teen safety, health and wellness it seemed appropriate to ask Fran to share some insights about her important contribution.

Chodzinski: Your career in teaching and publishing is extremely interesting. You have been influential in publications that are helpful to parents and educators throughout the world. What prompted your interest in this sensitive publishing project? stand." (page 143)
Fearnley: What really appealed to me about this project was that we were going to present the voices of youth in their most authentic form. While I have always appreciated the role of informed, empathetic adults (parents, professionals and others) in interpreting the experiences of children and youth, the journalist in me believes that to truly understand emotionally nuanced situations you should, if possible, go to the source.

Chodzinski: The focus of this issue of Teaching and Learning is health, safety and wellness of children in schools. The stories printed in your book demonstrate an uncanny will to survive and speak to many important life coping skills. What struck you most about the stories and how did editing this book make a difference to you?

Fearnley: I deliberately selected stories that did reflect the resiliency and will to overcome the terrible situation these teens were living. We wanted the book to give its readers a sense of empowerment, should they find themselves victims of violence, or tempted to be violent themselves. Sadly, we also heard from many youth (whose stories we did not publish) who have not been able to turn things around, and who are still involved in self-destructive behaviours and unable to come to terms with what they have experienced.

What struck me most is how exposed and vulnerable many young people feel, even when they have a caring family to turn to. The need to appear strong and able to cope, or to hide the brutality experienced at home or in school, is part of the pressure youth feel from peers and from 
society as a whole.

Violence is hard to talk aboutfor anyone of any age-but editing this book really brought home how much more difficult that is for young men. It is not surprising that suicide rates for male teens are much higher than their female counterparts. It is important for them to be seen as tough and unafraid - even boastful about how they have handled aggression and violence.

Chodzinski: Many of these stories graphically represent a very violent world in which students live. What do you envision readers will feel and think about the reflections printed in the book?

Fearnley: First and foremost, I think they will respond to the authenticity of these stories. They will believe them and that is very important. Many of our teen readers will also, I hope, see how there is no such thing as being neutral when it comes to violence. We all have a role to play in reducing or preventing violence.

What I think they will also understand from these accounts, is the complexity of the dynamic between the bully and the victim. Debbie's story about an abusive boyfriend (who, ironically and sadly, works with at-risk youth) is an excellent example. Debbie is an attractive, bright young university student with a loving family who finds herself in a confusing relationship with her live-in boyfriend. He never physically abuses her, so it's hard for her to figure out what she can accept as the normal ups and downs of an intimate relationship and what is unacceptable and destructive.

Debbie tells us how, with the benefit of hindsight, she was able to see how the abuse started, how and why she stayed in denial for some time, and the importance of having a loving, supportive family to turn to and give her the strength to leave him. It was that love and support that helped her write a letter to her boyfriend, also a victim of a violent childhood, explaining why she needed to leave him and start a new life.

Ihope by reading these accounts, and the excellent closing chapter by Dr. Fred Mathews, readers will come away with a visceral understanding of how violence happens and how vital it is for victims and bullies to find help.

What struck me most is how
exposed and vulnerable
many young people feel,
even when they have a
caring family to turn to. The
need to appear strong and
able to cope, or to hide the
brutality experienced at
home or in school, is part of
the pressure youth feel from
peers and from society as a
whole.

Chodzinski: The stories speak about life in Canadian schools, on the street and in the home, and how they, the authors, were abused, ignored and abandoned by friends, parents, teachers and the community at large. In you opinion, what can teachers learn from these stories and perhaps, even more important, how might they and school boards in general use this book to foster a better understanding of students in crisis?

Fearnley: One very simple way would be to use the book to open dialogue with the students. Could these events have happened in their school? If so, why? What in the school's culture allows violence to flourish? I think there is too much happening that teachers would rather not know about, and so they turn a blind eye. Moreover, there is too much that the students want to keep hidden. That is an unhealthy combination.

It is very important for schools to foster an environment where victims and bullies can break the cycle. Too often, the aggressor's behaviour is a cry for help, so if the school's response does not include going to the root cause then nothing will be solved.

Chodzinski: Anyone who reads this book will find the stories true to the voices of those speaking. The accounts are edgy, violent, and graphic and yet portray a sensitivity and caring side despite the violence. One desperate grade eleven voice sums up much of the tone of the book," I just suddenly broke down. My body broke down. I had no reason to live. I had no family here-except my brother-any friends; I hated life so much that I decided to suicide. I went to one of the worst areas of the city. I decided to go there to get myself killed. I was there for hours. No one seemed to want to beat me up. No one seemed to want to hurt me. [...] I met a drug dealer and the next morning I woke up, he raped me... I look at problems as a game. I believe God gives you problems to prepare you for life; to prepare you to grow up; to help you build strong selfesteem; to be a person to fight this world. That's how I got through it.

Fran's book I Wrote on all Four Walls Fran Fearnley, Editor, is available through Annick Press, Toronto, distributed by Firefly Books, 66 Leek Crescent, Richmond Hill. ON, LAB1H1. ISBN 1-55037-756-6. 
My book, Bullying: A Crisis in our Schools and our Communities. Raymond T. Chodzinski, is available through editions Soleil publisting inc., P.O.Box 847, Welland Ontario, L3B 5Y5, Fax order desk 1800-261-0833. ISBN1-894935-02-0.

Fran Fearnley is an accomplished author, editor and freelance jour-

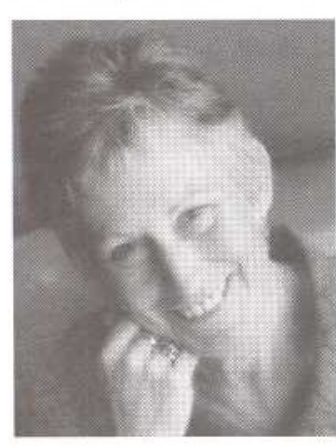
nalist. Her career path includes teaching high school, corporate relations advertising, film production, and development of various publication products. She served as an elected school trustee Peterborough, Ontario, for six years. Her career has taken her to the University Of Natal, South Africa as an associate publisher and as a volunteer managing the Electoral code of Conduct during Natal's second democratic election.
Iranian by birth she has traveled extensively through out Africa and Europe and has written about those experiences. Ms. Fearnley is widely known as the former editor-in-chief for Today's Parent Group and for her ten-year contribution as editor of the very successful Today's Parent Magazine and her work as project manager for Kids have Stress Too, sponsored by the Psychology Foundation of Canada. She is actively involved in interests that promote global education and understanding.

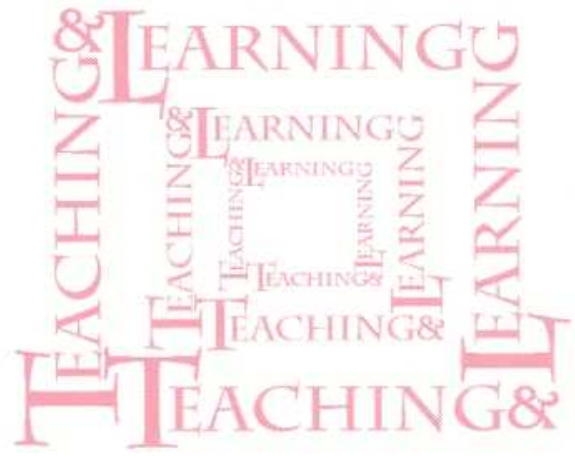

In a recent article about youngsters interviewed and cared for by Halton Health Services Youth in Transitions Program (TFY) revealed that 30 percent of youths in program were judged to be at a high risk of suicide. The report states that 100 percent of the 164 youth aged 12-17 in residential custody, and detention programs had mental health challenges and 52 percent were diagnosed with serious mental

health disorders. Melanie Hennessey of the Burlington Post ( $p g$. 19, 3010 2005) wrote that of the group represented, 71 percent were at high risk of violence, 47 percent

were at risk of substance abuse and 15 percent were at high risk of setting fires. Also 100 percent of females in the program had suffered some sort of abuse, many of a sexual nature.

Most of these young

people have been involved in the justice system, are homeless or at risk of becoming homeless and 90 percent used or abused drugs and or alcohol. 